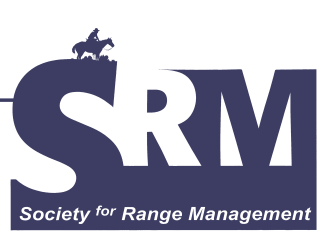

\title{
Historical Weather Patterns: A Guide for Drought Planning
} By Alexander J. Smart, Barry Dunn, and Roger Gates

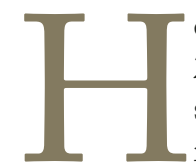
ow do we know when drought will occur? In 2002, the Great Plains suffered through a widespread drought that seemed to catch many ranchers off guard. In South Dakota, there was a flurry of extension activity generated to deal with drought issues. Why were so many ranchers caught off guard? One answer may reside in the patterns of past weather data. Being able to anticipate low rainfall and having the flexibility to handle it has been the common advice by extension personnel and ranchers that have successfully weathered the years. To do this, one has to develop the ability to evaluate historical data in regard to making decisions that have long-term implications for successfully navigating through ranching challenges. Our objective is to present historical precipitation data from western South Dakota and derive certain expectations of drought occurrence to show how this can be used in drought planning.

\section{Annual Precipitation Patterns}

It is well understood that the amount of precipitation in semiarid environments is the main factor that determines forage production. The Cottonwood Range and Livestock Station in western South Dakota has been recording weather data since 1909. The power of such information is that patterns emerge that can provide insight into the future, allowing preparation. It is not a crystal ball but at least an informed guide.

Drought is generally defined as $75 \%$ of average annual precipitation. At the research station, annual drought occurred 14 times out of 95 years of weather-data collection

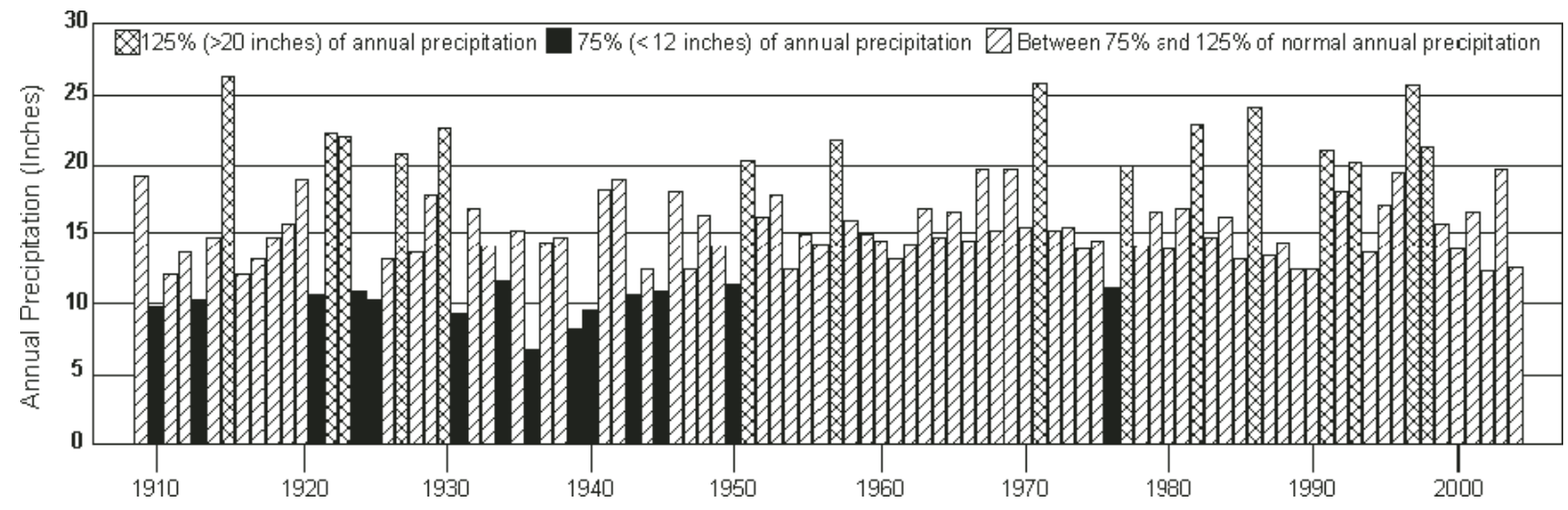

Figure 1. Annual precipitation from 1909 to 2004 for the Cottonwood Range and Livestock Station located 75 miles east of Rapid City, South Dakota, in the mixed-grass prairie. Mean annual precipitation is 16.04 inches (USDC 2004'). 


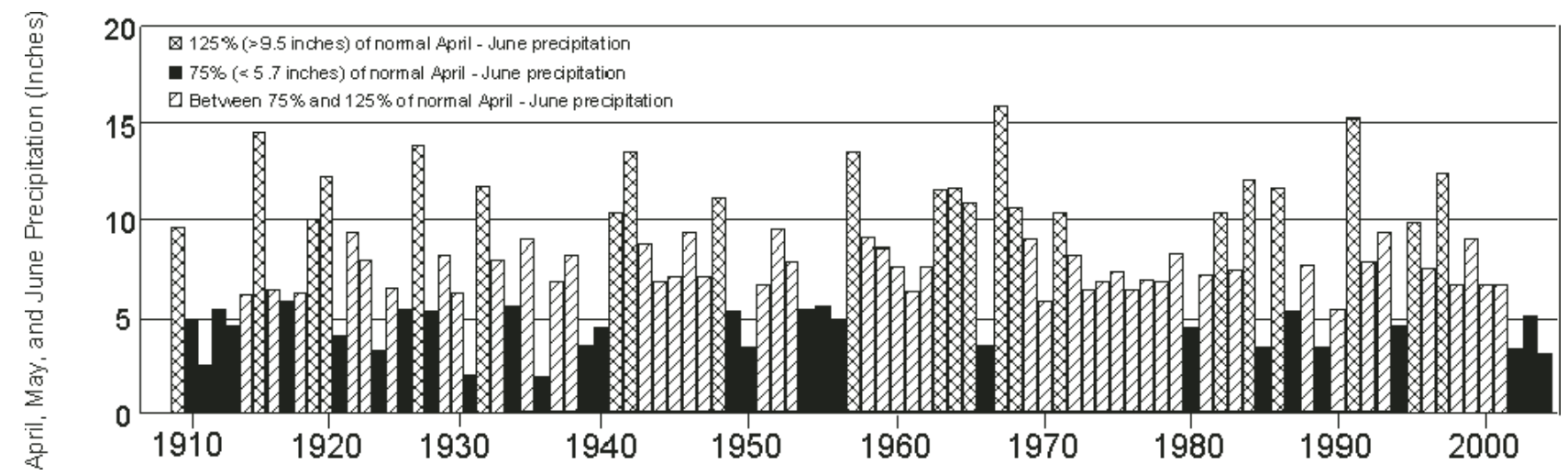

Figure 2. Cumulative precipitation for April, May, and June from 1909 to 2004 for the Cottonwood Range and Livestock Station, located 75 miles east of Rapid City, South Dakota, in the mixed-grass prairie. Mean precipitation for April, May, and June is 7.6 inches (USDC $2004^{1}$ ).

(Fig. 1). The last 50 years at the research station have been wetter. However, this might not reflect the true impact on forage-growing conditions because the timing of precipitation in a temperate climate is as important as annual precipitation.

\section{Spring Precipitation Patterns}

In the northern mixed-grass prairie of the Great Plains, the amounts of spring precipitation for the months of April, May, and June are particularly important as indicators of the current year's forage production. In a South Dakota agricultural experiment station bulletin published in 1951, ${ }^{2}$ the authors recognized this phenomenon and also noticed that summer precipitation was $75 \%$ of normal 6 out of 7 years. Because the warm-season grasses consist mainly of shortgrasses, such as blue grama (Bouteloua gracilis [H.B.K.] Lag. Ex Griffiths) and buffalograss (Buchloe dactyloides [Nutt.] Engelm.), late-summer rainfall did little to increase the season's total forage production because the cool-season forages had already produced the majority of their biomass for that year. In 2004, Heitschmidt ${ }^{3}$ confirmed this by examining 15 experiments in the northern Great Plains and found that $91 \%$ of the annual forage was produced by July 1 .

Cumulative spring precipitation data for the months of April, May, and June from 1909 to 2004 are presented in Figure 2. As one would expect, spring precipitation was highly variable over the 95 years. Above normal $(>125 \%$ of the 95 -year average), normal, and below normal ( $<75 \%$ of the 95 -year average) occurred $23 \%, 48 \%$, and $29 \%$ of the time, respectively. Looking at the decades of the 1910s through the 1950s, below-normal spring precipitation occurred nearly $40 \%$ of the time while only occurring $15 \%$ of the time from the 1960s to the 1990s (Fig. 2).

\section{Knowing What to Expect}

While it's uncertain what the future will look like, looking at the occurrence of past events gives us an idea about what kind of spring rainfall could be expected given the current rainfall pattern. For example, in 2001, the research station had received 7 consecutive years of above-normal or normal spring rainfall since 1994 (Fig. 2). Given this pattern, the frequency of occurrence of 8 consecutive years of above-normal or normal spring rainfall was very low. In fact, such a pattern only occurred 1 time out of 27 periods, or 4\%, between years with below-normal spring rainfall during the last 95 years (Table 1). It shouldn't have been a surprise when drought came in 2002; actually, it might have been anticipated because long periods ( $>4$ ) of normal or above-normal spring-rainfall years between spring-drought years are quite low (Table 1).

Back-to-back below-normal spring rainfall occurrence was $33 \%$ (Table 1). So when a spring drought does occur, it is not unreasonable to anticipate that another year of belownormal spring rainfall could follow. The good news is that consecutive years of spring droughts don't last as long as the number of years with above-normal or normal spring rainfall (Fig. 2). Most dry periods came in 1-year intervals with below-normal spring rainfall occurring 19 times during the 95 years (Fig. 2). The longest drought lasted 4 consecutive years but only occurred 1 time (Fig. 2).

\section{Conclusion}

Understanding historical patterns can lead to effective planning for successfully managing ranch resources. Historic weather records are available and readily accessible for most of the United States. In addition, keeping track of precipitation is probably standard practice on most ranches. In the northern Great Plains, spring rainfall is a better indicator of forage production because this rainfall overlaps the growing conditions for most cool-season forages. Ranchers should expect below-normal spring rainfall to occur about $30 \%$ of the time and should plan accordingly. Learning to be sensitive to recent weather patterns and assessing risk will help alleviate the financial struggles and degradation in rangeland resources caused by droughts. In western South Dakota, if 
Table 1. Number and frequency of normal or above-normal spring (cumulative April, May, and June) rainfall years between years having below-normal spring rainfall at South Dakota State University's Cottonwood Range and Livestock Station from 1909 to 2004

Normal or above-normal spring rainfall years between years having below-normal spring rainfall

\begin{tabular}{|c|}
\hline Event \\
\hline 0 \\
\hline 1 \\
\hline 2 \\
\hline 3 \\
\hline 4 \\
\hline 5 \\
\hline 6 \\
\hline 7 \\
\hline 8 \\
\hline 9 \\
\hline 10 \\
\hline 11 \\
\hline 12 \\
\hline 13 \\
\hline Total
\end{tabular}

\section{Times occurred}

\begin{tabular}{|c|c|}
\hline No. & $\%$ \\
\hline 9 & 33 \\
\hline 5 & 18 \\
\hline 3 & 11 \\
\hline 4 & 15 \\
\hline 2 & 7 \\
\hline 0 & - \\
\hline 0 & - \\
\hline 1 & 4 \\
\hline 1 & 4 \\
\hline 1 & 4 \\
\hline 0 & - \\
\hline 0 & - \\
\hline 0 & - \\
\hline 1 & 4 \\
\hline 27 & 100 \\
\hline
\end{tabular}

several favorable spring-rainfall years have occurred in a row, ranchers can probably anticipate a spring drought to occur within the next year or two. If a spring drought does occur, history suggests that the next year's spring could be dry because back-to-back spring droughts occurred $33 \%$ of the time. We believe that being able to anticipate low rainfall and stock at conservative rates or have flexible stocking alternatives is still the best advice from extension personnel and ranchers that have successfully weathered the years.

Authors are Assistant Professor/Range Scientist in the Department of Animal and Range Sciences at South Dakota State University in Brookings, SD (Smart); Executive Director and Endowed Chair of the King Ranch Institute for Ranch Management at Texas AE $M$ University-Kingsville in Kingsville, TX (Dunn); Assistant Professor/Range Extension
Specialist in the Department of Animal and Range Sciences at South Dakota State University in Rapid City, SD (Gates).

\section{References}

1. US Department of Commerce. 2004. Climatological data (1909-2004). Washington, DC: National Oceanic and Atmospheric Administration. Available at http://www.ncdc. noaa.gov/oa/ncdc.html. Accessed 31 December 2004.

2. Johnson, L. E., L. R. Albee, R. O. Smith, and A. L. MOXON. 1951. Cows, calves and grass: effects of grazing intensities on beef cow and calf production and on mixed prairie vegetation on western South Dakota ranges. South Dakota Agricultural Experiment Station Bulletin 412.39 p.

3. HeitschmidT, R. K. 2004. Drought management-do you have to run out of forage before managing? Abstracts: Rangelands in Transition. Society for Range Management 57th Annual Meeting; 24-30 January; Salt Lake City, UT. p 77. 